\title{
Family Ethics in Celeste Ng's Everything I Never Told You
}

\author{
Yuan Shen \\ University of Jinan \\ Jinan, China
}

\author{
Ting Yang \\ University of Jinan \\ Jinan, China
}

\begin{abstract}
Chinese American writer Celeste Ng's novel Everything I Never Told You penetrates into the educational crisis in a mixed-race family by highlighting the sense of alienation, frustration and depression resulting from distorted family ethics. This paper mainly analyzes the ethical issues in the novel from the perspectives of conjugal ethics, parent-child ethics and sibling ethics. According to Hegel, conjugal ethics requires both parties' unification of personality, and their acknowledgement of the entitativity of a family, while James and Marilyn failed to do so. Apart from that, James' estrangement from the children and Marilyn's high expectations for Lydia made them suffer from post-traumatic stress disorder, and gave rise to Lydia's death. Moreover, the issues of excessive attachment, escapism and invisibility aroused by siblings obstruct a normal intersubjectivity. Celeste $\mathrm{Ng}$ thus underscores the significance of wholesome family ethics for children's growth and cultivation.
\end{abstract} ethics

Keywords-Celeste Ng; Everything I Never Told You; family

\section{INTRODUCTION}

Ethics is a kind of social morality and it has been developed for a long time. Generally speaking, ethics is a science which is a study of morality and it's a branch of philosophy (Luo, 2003: 2). "Family ethics is the name for a group of ethical problems. Persons interact as family members, person intends to join, create or dissolve" (Houlgate, 1999: 1). Family ethics is also called family morality; it aims at adjusting family relationships and specifying family members' behaviors. A good family ethics can maintain family harmony and social stability. Everything I Never Told You which tells us a girl with the sense of insecurity had been catering to her parents all the time in order to keep her family together after her mother ran away from home in her early years and finally she took her own life. At the beginning of the book, the writer has written "Lydia is dead" (Ng, 2014: 1). Readers may take notice of why Lydia chose to end her own life, what has she experienced in her daily life and how her family and friends treated her. It seems that something was wrong in her family and she can't bear such a kind of burden. Who should take responsibility for her death? Her mother? Her father? Or her siblings? Therefore this paper will focus on her family relationships and family problems. By analyzing Celeste $\mathrm{Ng}$ 's detailed description of the whole family, this thesis will find the causes of Lydia's death and how family ethics effects them in mentality and physiology imperceptibly.

Based on family ethics analysis, this thesis has four parts in total: (1) Marital ethics and extramarital ethics; (2) Parentchild ethics; (3) Siblings' ethics; (4) The writer's ideal family ethics. Through the four-step analysis, family ethics in Everything I Never Told You will be understood clearly and it's not an abstract conception anymore. We will better understand family ethics' function to people and society through reading all about Lydia's family life.

\section{DisLOCATED CONJUGAL ETHICS}

\section{A. James' Inhibition in Marriage}

In the early twentieth century, America still had been influenced by Chinese Exclusion Law. James' father went to California under a false name like many others Chinese immigrants did at that time. Due to this, most Chinese immigrants felt alarmed all the time as if anyone could figure out that they had stolen into America and officials would repatriate them to China. So they had been trying their best in integrating into the American daily life and wanted to disappear in the crowd.

James was the first eastern students to attend Lloyd $(\mathrm{Ng}$, 2014: 43). His classmates and schoolmates were curious about this eastern boy and they had been talking about him behind his back. It made him uncomfortable and he began to pretend as an ordinary student. Schoolmates' excessive concern made him a sensitive and self-contemptuous boy. He didn't find acceptance by his classmates although he had been trying to contact with them. When James fell in love with Marilyn and they were living together before they got married, he felt that America opened the door for him because Marilyn accepted him. Marilyn looked like his lifesaving straw since insecurity was inundated with his heart. Before they got married, Marilyn just knew that James' parents had gone for years. James never told her that how his parents came into America and how his family had been living in this country. Cause the economic independence doesn't represent completely racial equality and cultural identity (Elliot, 2005: 435). Yet he was afraid of talking about that because he knew once he told her the facts that all of his image would be collapsed. 
Chinese traditional family ethics stresses that men should take charge of social affairs and women should take charge of domestic affairs. According to traditional views, a wife should stay at home to deal with daily trifles such as cooking, cleaning, washing. If a women leave home for work, her husband may feel ashamed. James knew his wife want to be a doctor but he persuaded Marilyn never considered about going to work when his colleagues invited Marilyn as an assistant. Because he knew he would hear some gossips from his neighbors. For his man's dignity, he won't let Marilyn go to work and mention this again. After Lydia's death, James commanded police to send Lydia's autopsy report to his office, not his home. He refused the request that Marilyn wanted to take her last look at Lydia. All his behaviors showed male chauvinism which originated from the ideal of Chinese traditional family ethics and it had been emphasizing men are superior to women. James stubbornly persisted in his opinions and ways to deal with his daughter's death and relationship with Marilyn. He never asked for Marilyn's request and Marilyn was merely a housewife in his mind. Finally his male chauvinism and inhibition in marriage intensified their family conflicts and became an obstacle emotionally.

\section{B. Marilyn's Disillusionment with Marriage}

Mrs. Walker was a home-economics teacher in Radcliffe and she had been giving this course to students for almost a dozen years. She had infinite faith that a women should live like as a woman. Women should do well in housework and all dress up when their husband arrived at home. But Marilyn didn't follow her; she didn't want to be a housewife or nurse but a doctor. She finished physics and chemistry course perfectly and refused to attend home economics course. As she said to Marilyn "I know what you're trying to prove. But believe me; I will fail you if you keep this up" ( $\mathrm{Ng}, 2014$ : 29). The words from middle-aged women were in line with her life experience, but Marilyn was adamant that she would not live as her mother. Her first encounter with James was in the course of the American Cowboy Culture. It is also the first time she got touch with an oriental and she never met such a general person who might get her out of the ordinary. After she married James, she started a housewife's life. But she refused to surrender to reality, she ran away from home to school after she prepared enough food for family, but unfortunately she found herself pregnant over again. Reluctantly, she had to go home and raise her children while her dream was shattered. All her family went quiet.

Moral principle is the core of ethics and it has important significance to the principle of individualism in different forms. It emphasizes personal value, dignity, freedom and equality in terms of standard and independence (Luo, 2003: 173). The pursuit of human freedom, the western independent thought and individualism happened to hold the same view. Throughout the twentieth Century, due to the constant feminism movement, Marilyn had right to education and it made her get closer with her doctor dream, but women were still under pressure and discrimination in employment and education and people didn't fully accepted the role of women in all walks of life. She had been imaging that career could be combined with family, then she met with Doctor Woolf who lived in the corner of street and she thought that she could be a female doctor as Mrs. Woolf did. Since then in order to achieve self-worth and pursue her dream she left her husband and children alone, she did not expect to receive any support from her husband, all depended on her own efforts, it seemed that it was very admirable in others, but once her fighting alone had become a habit that would make her increasingly selfish. That is typically individualistic. But in the end, due to the children's attachment, the moral conscience and condemnation and the moral obligation for the whole family, the pregnant Marilyn had to return to the reality that her dream was also disillusioned at the same time.

\section{The Extramarital Marriage}

Louisa was the first oriental student that James had ever met and she looks like her favorite daughter Lydia. In the fall semester, Louisa was fortunate enough to become an assistant professor of James. From her, we can see the typical oriental women with gentleness, tenderness and submission. When James lamented over his hard work, she could comfort him by saying "your life is not wasted". When James' hand through over her shoulder, she immediately blushed $(\mathrm{Ng}$, 2014: 10-11). At least, she liked James at that time. When James saw his daughter's autopsy report hopelessly, she invited James to her home, more specifically to her bedroom and since then these two people began an illicit relationship. "You're the kind of girl I should have married" (Ng, 2014: 205). Because of this, Louisa began to imagine that James would divorce with Marilyn and marry her. Until Marilyn found them, she began to be panic but still deceived herself that it was just a coincidence, but in the end James only said a goodbye to end their relationship.

Love is a kind of ethical relationship with emotional tension and speech value in human relationships. Society advocates the proper love which is a right that only single youth or widowed elderly has and it should be supported by all aspects. "We love a person, because we think that person has the qualities we respect". Rousseau has stressed (Luo, 2003: 295). Both Asians came together because of their intimacy and perception of affiliation and they had the same cultural foundation and the way of thinking. Louisa was the first oriental student James had contacted with, then she became the assistant of James, it can be easily understood that they have tender feelings with each other gradually. Modern love is based on mutual love, obviously James was only to find an outlet for feelings rather than get rid of his family to marry Louisa, but her dream was to marry him, so their relationship was unequal and abnormal from beginning to end. They only considered about releasing their own desires and didn't care about their own moral obligations and future planning. The love which can destroy others' family should not exist, so after Marilyn knew her existence, Louisa was mercilessly abandoned and James even felt ashamed of their relationship. Rousseau said the most important female quality is a gentle, docile personality (Luo, 2003: 284). The gentle and docile character of Louisa had made James had psychological dependence and greatly satisfied his heart with male chauvinism. Perhaps if she had adhered to the moral 
bottom line from the beginning, the tragedy that finally she was abandoned would not have happened.

\section{DISTORTED PARENT-CHILD ETHICS}

\section{A. Mother-daughter Relationship}

Lydia was fortune but also unfortunate. The fortune was that she perfectly inherited the physiological advantages of her mother Marilyn, so Marilyn had a predilection for Lydia. It seems that Lydia was a pearl in the palm but this preference also made her plunge into the abyss. Marilyn once got away from her family for the sake of her doctor dream, and young Lydia thought it was certainly that she did something wrong and made her mother too angry to stay at home, so she secretly vowed to meet all her mother's wishes to ensure that Marilyn won't leave. Marilyn did not fulfill her dream and then she had been planning her own life and imposed the dream on Lydia. She asked mathematical questions to Lydia at any time, the annual birthday gift was unshakable science books. When Lydia walked into the kitchen, Marilyn thought was there must be something she had missed, what else didn't she know and she wasn't feel happy for her walk; when Lydia physical scores began to decline, Marilyn only have Lydia endless rebuke and didn't give any chance to Lydia for explanation. In the end, Marilyn found condoms and cigarettes in Lydia's bag, and then she doubted whether she had understood her daughter. Actually, she had been imposing a variety of requirements upon her daughter without real mutual understanding.

On the other side, young Lydia spent her days carefully after Marilyn had come back, she had counting how many hugs did her mother gave to her and how many words her mother said. Every night she would confirm whether she could see her mother tomorrow and Lydia was always said yes, yes, yes. All of these yes means by tedious tasks and wishes that constantly expressed by her mother. Gradually the adolescent Lydia had realized that except for being a doctor, she had no alternative. Maybe due to her mother's pressure or she wanted to get rid of everything here, Lydia eventually chose the most extreme form of escape: suicide.

Ethics emphasizes on teleology, the teleology considered that all human behavior is due to a purpose and they want to achieve an ideal result (Luo, 2003: 417). Family teleology maintained integrity of family harmony and peace. Because the young Lydia wanted to ensure that Marilyn would no longer run away from home, then she chose to continuously achieve requirements of Marilyn. This is a kind of moral behavior based on family ethics, a conscious, voluntary and self-selected behavior she had chosen. She represented the entire family's will and as the core of the family, she was not only responsible for her parents' ideals but also responsible for the maintenance of family harmony. People are social existent which have ability to thinking, volition and disposing capacity (Luo, 2003: 317). When Lydia was young, her parents controlled everything about her. Gradually with the maturity of personality, self-differentiation can be changed (Skowron, 1998: 235-246). But when she had grown up, her independent consciousness had constantly improved, it indicated that parents should regard her as an independent person. Marilyn should communicate with Lydia but she never compromise her doctor dream.

Personal value conflicts means conflicts about moral obligations. The conflicts between Marilyn and Lydia were mainly reflected in the following two aspects: Firstly, Marilyn's job expectancy for Lydia was a doctor, but when Lydia grew up she found that she had difficulty in science and she wanted to give up. Besides they couldn't communicate well on this issue, then two extreme opposites had appeared into her mind: one was continuing her education; the other was to escape from all pressures. It's obviously that Lydia preferred to freedom. Secondly, a child has grown up and become an independent and unconstrained person with deep self-consciousness. If parents still arrange everything for children and continue to control their future, it would cause sharp value conflicts in the children's heart. Marilyn didn't realize that Lydia had grown up, refused to communicate with Lydia and eventually caused her daughter's suicide.

\section{B. Father-children Relationship}

James was very concerned about her daughter's personable manners. He had carefully selected her daughter's photos when the police asked for him. As if he firstly had acquaintance with Marilyn, he was always flicking his stubborn hair. It looks like he was care about manners actually he took notice of primary impressions by others. After the police started investigation, James was conscious of the fact that Lydia didn't call her friends for a long time. Lydia had done something else and cheated on her parents; after all, the bolt can't prevent her to do any choice.

How about Lydia? She firmly believed that her father was different from mother and at least he could understand her like her brother Nath. This year, she was expected for her Christmas gifts which selected by her father personally. But when she opened the gift, she found a book named "How to Win Friends and Influence People", James thought Lydia might need this book and she could learn how to deal with interpersonal relationship. But for Lydia, it added insult to injury. James never told her about his childhood but sensitive Lydia had guessed that her father might suffer from interpersonal relationship. So she pretended to be very appreciated for this gift and said nothing. Think back to the previous, it's her father urged her to call on her friends, it's her father urged her to date with her friends. James hoped that Lydia could owned many friends and remedy for his childhood defects.

Intergenerational ethics is a generic term of human ethic relationship between generations and ethic specification and it's an important part of social ethic relationship and ethic forms (Zhang, 2007: 3). If generations lack communication, it will lead to irreconcilable contradictions. In accordance with traditional family ethic ideals that men outside and women inside, James was working at school in the daytime and he could only communicate with Lydia after he got off work. But in the short time, James was only emphasized the importance of making friends repeatedly and he never cared about the inner world of his daughter. In the history of 
western ethics, Kant emphasized that the reason why an act is called good and has moral value is that it is based on a good will. The starting points of James were good, but Lydia was under Marilyn's pressure for a long time and then James began to intervene in her interpersonal relationship. All of these made Lydia didn't feel the warmth of home, finally she chose death to end of her life.

Meanwhile, western ethic ideology history stresses consequentialism which is also called motive theory (Luo, 2003: 416). James always reminded Lydia the importance of love and friends, urged her to date with her schoolmates and even sent her a book to teach her how to make friends. At last, all his behaviors became one of blasting fuses to make Lydia commit suicide. If he had communicated with Lydia and notice her heart fluctuation timely, Lydia would not have suicide. James is a good father because he provided a decent family environment for his family; but also he is a failure because he killed his children.

\section{Father-son Relationship}

Chinese traditional family ethics stress males are supposed to be worthier than the other sex. Nath was the only male child in his family. James pushed him to learn swimming and play games with other strange schoolmates. But they were not friendly enough, they played jokes on Nath, it made him ashamed. However, James just wanted to wake Nath up and force him to be a better man. Nath was too "thin" to attend rugby team; he was too "short" to play basketball; he was too "foolish" to play baseball, he can only make friends by reading, researching map and playing telescope (Ng, 2014: 92). Through this, James felt the most painful blow. Nath couldn't be the boy who was in his mind. When Nath met with astronomy program by accident, he was trapped in it and talked about it with his father day by day. But James just slapped Nath because he thought there's no value on searching astronomy and he never mentioned this again. James often looked at Nath despondingly even he had received Harvard's offer.

Although James was living in the United States from an early age, his ideas were still influenced by Confucianism. In the aspect of family education, Chinese traditional Confucian family ethics emphasize that children have the duty to support their parents; the most important is complying with parents and regarding parents with reverence. The ideal Nath in James' mind was a boy endowed with civil and martial virtues hence he compelled Nath to learn swimming, join rugby team, play with other kids and everything he wanted, but it didn't work at all because of Nath's physical fitness. Owing to these, James was increasingly despairing of Nath then began to detest him. As a father, his duty not only lies in feeding their children but also raising their children mentally which is called paternal love. James liked the boy who could yield in him, become him and surpass him. His son should accomplish all his requirements as many oppressed Chinese children do. But Nath was born in America and from childhood he was under the western education. Western family ethics emphasize individualism so Nath was chasing his dream silently when his father was indifferent to his astronomic career. Nath was enrolled in Harvard where his parents were also dreamed of, yet he didn't grab his parents' attention. All he wanted was only his father's affirmation, nevertheless, he failed. James should encourage him to chase astronomic dream and share experiences with him as elders so that the whole family would be harmonious. Their relationship also indicated the conflicts between Chinese and western family ethics. One emphasizes wholeness and the other emphasizes individualism. Individuals are subordinate to family and family is consisting of individuals. As the saying goes, while water can carry a boat, it can also overturn it. A good paternal relationship can promote family harmony all the time.

\section{ETHICAL ISSUES AROUSED BY SIBLINGS}

\section{A. Lydia's Attachment to Nath}

Nath was not only the elder brother of Lydia but also the intimate friend of her. "Only Nath had made it bearable all that time. Every day, since kindergarten, he saved her a seat in the cafeteria, a chair across the table from him; on the bus, his books placed beside him on the green vinyl seat. If she arrived first, she saved a seat for him. Because of Nath, she never had to ride home alone while everyone else chatted sociably in pairs; she never needed to gulp out, "Can I sit here?" and risk being turned away. They never discussed it, but both came to understand it as a promise: he would always make sure there was a place for her. She would always be able to say, someone is coming. I am not alone" (Ng, 2014: 166). Nath was the only one who could give him the warmth of family, as an elder brother, he gave too much warmth whether as a family member or a friend. The warmth made Lydia has hoped to carry on. After Lydia knew her brother would go to Harvard, she concealed his admission offer and wanted to cheat on him that he wasn't admitted. Fire cannot be wrapped up in paper. The neighborhood Jack had sent the admission letter to her family. Nath expressed a strong desire to get out of here although Lydia made every attempt to stop him. Lydia commanded her brother to call her at school. Nath became busy and more and more impatient with Lydia until her death.

Siblings are the most intimate persons in the world except parents. Actually, Nath had done his duty as an elder brother. According to western family ethics, every family member has the right to pursue their own dream and they live for themselves, not for their family. Learning is a normal thing in everyone's life but Lydia didn't think about that. She tightly caught hold of Nath in case that he should escape away from her. As his young sister, Lydia should spare no effort to support her brother to finish schooling. Siblings should help each other and respect individual differences, Lydia can also escape from here in the same way as her brother. The western family emphasizes too much on personal independence and it will lead everyone crazy on their own needs while ignoring the presence of others. It's also the reason why Lydia just wanted to detain her brother and Nath and wanted to escape from here. 


\section{B. Nath's Escapism}

After Marilyn ran away from home, Nath and Lydia these two siblings were counted the time by watching TV. Accidentally, one day they were watching an astronomical program and then he was indicated to it every day and constantly repeated astronomical professional terms at home. Every day he would read the Astronomical Journal, collect the latest astronomical information from various sources, cut down some interesting parts and hide them into folder. He was hiding in his room and study astronomy all the time cause his parents didn't care about him. Less parental cares saved a great deal of time for him. He wanted to escape and detach from the emotional attachment from his family (Goldernberg, 2004: 188). After he successfully applied for Harvard, he was imaging what his future would be like continuously. There was a long time before he leave here yet he had packed everything. He didn't want to spend one more time in this home and leave here in haste.

As the result of deficiency in parental love, he can only indulge in his world. Only astronomy can render happiness and gratification to him. Ethics holds that egoist can be expressed as hedonists pursue of personal pleasure, as well as utilitarians pursue of personal happiness and even expressed as "Love his neighbors" for their own happiness by means of altruist (Moore, 1983: 106). In spite of winning parental attention, Nath had tried in many times but he failed so that he wanted to escape from here. In family ethics, we stress everyone is equal. But his parents gave their full attention to Lydia which made Nath uncomfortable and it's the reason why Nath wanted to escape. Parents should treat every child as their friends, communicate with them equally, give audience to their children and it can be more conducive to the growth of children.

\section{The Invisibility of Hannah}

Hannah was the youngest children in a family that parents gave too much attention to her elder sister. She often hid under dinner table and some inconspicuous corners at home. All family members turned in a blind eye to her. She never dared to get too close to her family because her parents and siblings would fling her off. Her hobby was collecting articles which her family used and discarded. Even though she was young and her family treated her like that, she still loves everyone. After her sister's disappearance, Hannah once wondered the life without her sister, she would sit in the best seat on the table and live in big bedroom and parents would give her all the best. But that's a wishful thinking. She knew everything about her family yet no one wanted to know her. After Lydia's death, her parents found that they had a daughter and Nath realized he had only one sister at that time.

The family had been snubbed Hannah for long time so she could not but observe family in the corners. Hannah was as unfortunate as her brother because they had the same experience. However, she was too young to extricate herself from her family. Her parents didn't do their parental liability; it made her sensitive and scrupulous. Healthy environments can mould a healthy personality. In Hannah's age, children should live in a carefree life but Hannah did not. So who should responsible for this? "Like everything: with mothers and fathers" ( $\mathrm{Ng}, 2014: 25)$.

\section{CEleste NG's IDEAL FAMILY ETHICS}

\section{A. Love and Equality}

Although Celeste $\mathrm{Ng}$ has been living in America for many years and deeply influenced by western family ethics, we will find there are many Chinese traditional family ethical elements in her work. Commendably she can apply this to literature works.

Modern Chinese family ethics advocates freedom of marriage. Modern marriage is based on free love. Engels pointed out that "In case the marriage based on love is moral and then only keep love in marriage can be called moral" (Engels, 1972: 78). Love is a powerful initiative in family because it is on the basis of definite social relations and psychological activities. Love can constantly adjust the relationships between spouses and become the basic moral guarantee of marriage. Therefore, family is connected with emotional bonds between spouses and children. The marriage of Marilyn and James was based on love but it contained disguises because Marilyn concealed the truth that her mother had racial discrimination against James and James disguised his antecedents. Ethnic identity represents a person's ascription and it's determined by physical, geographical, social, cultural conditions and so on (Xu, 2008: 196). James regarded him as an American and laid stressed on American culture. He deliberately effaced his Chinese part for Marilyn. So the marriage is free but not pure. If these three children had been treated equally, Nath would not have escaped and Lydia would not have committed. It's clearly how important the love and equality is.

\section{B. Responsibility and Freedom}

In the light of traditional family ethics, men should in charge of external affairs and women should in charge of internal affairs. From the book, Celeste supports women go out to work but she also stresses the liability of a mother. In the family, the mood of people is an kind of awareness that they are in the unity, the essence of individuals is existence itself thus made themselves to be a member, not an individual (Hegel, 1979: 177). In a family, parental liability is to raise and educate their children. The liability of children is to support and assist their parents. You can't have your cake and eat it as you can't give consideration to responsibility and freedom. Marilyn was alike Baoyi in The Bonesetter's Daughter (Tan, 2001) who was pursuing personal independence and rebelling against traditional customs. Also western family ethics emphasized individualism that is personal interests greater than collective interests. But if Marilyn wanted to be free, she should assume her responsibility at first. Only people balance their family responsibility and personal freedom, can they be qualified for working. 


\section{Communication and Mutual Understanding}

Family communication helps people to promote parentchild relationships and maintain family harmony. Since childhood, James was discriminated all the time and it made him very sensitive to racial problems even talked with his wife Marilyn. Before they got married, they had promised slip from their memory and didn't mention it. After Lydia's death, James was always thinking that if Lydia was a white girl and Marilyn was collapsed. James was a male chauvinist so he objected Marilyn's going out to work and there was no room for negotiation. Modern family ethics emphasizes the equality between men and women. Anyway, spouses and siblings should have mutual respects and tolerance. About his daughter's death, he had blocked all negative news for Marilyn. Besides blindly accepted the way Marilyn spoke and educated, he was always remaining silence. Marilyn didn't communicate with his husband about her work and privately made a decision to continue her study without family permission. They didn't try to communicate with each other as they treated their children. We should treat our relatives as friends and listen to the voice of their inner world, thus building a harmonious family relationship.

\section{CONCLUSION}

Richard Posner suggests that ethical criticism should emphasize on "undeniably ambivalent works, works that seem to wobble around the moral center" (Krapp, 2002: 15). The theme of family ethics is an evergreen in literature. Celeste $\mathrm{Ng}$ particularly described the relationships between each member in family. Through the analysis of the whole family, we can see the importance of family ethics. Good family educations can contribute to cultivate a good character of teenagers. In contemporary society, many children are under the parental pressure like Lydia. Their lives are burdened with the expectations and dreams of their parents. Owing to parental incomprehension and peer pressure, suicide rates have been rising in recent years. As Celeste Ng said "How had it begun? Like everything: with mothers and fathers" (25). Through Lydia's death, she successfully aroused people's reflections on the construction of their own family ethics. She warns that we should cherish the moment and actively communicates with parents or siblings so as to avoid the occurrence of such tragedy.

\section{REFERENCES}

[1] Elliot, Emory. The Columbia History of The American Novel [M]. New York: Columbia University Press, 2005.

[2] Goldernberg, Irene and Goldernberg, Herbert. Family Therapy: An Overview [M]. Pacific Grove: Brooks/Cole Publishing Company, 2004.

[3] Guo, Linbo. A Study on Family Ethical Relationships in Gish Jen's Interracial Marriage Theme of Her Fiction [D].Beijing: Capital Normal University, 2012.

[4] Hegel, Georg. Elements of the Philosophy of Right [M]. Beijing: The Commercial Press, 1982.

[5] Houlgate, Laurence. Morals, Marriage, and Parenthood: An Introduction to Family Ethics [M]. Toronto: Wadsworth Publishing Company, 1999.
[6] Krapp, John. An Aesthetics of Morality: Pedagogic Voice and Mora Dialogue in Mann, Camus, Conrod and Doestoevsky [M]. Columbia: University of South Carolina Press, 2002.

[7] Luo, Guojie. Ethics [M].Beijing: People's Publishing House, 1989

[8] Moore, George. Principles of Ethics. Trans. Chang He [M]. Beijing. The Commercial Press, 1983.

[9] Ng, Celeste. Everything I Never Told You [M]. New York: Penguin Group, 2014

[10] Skowron, Elizabeth and Myrna, Friedlander. The Differentiation of Self Inventory: Development and Initial Validation [J]. Journal of Counseling Psychology, 1998, 6 (2): 235-246.

[11] Stowe, Beecher. Uncle Tom's Cabin [M]. Beijing: Centra Compilation and Translation Press, 2009.

[12] Tan, Amy. The Bonesetter's Daughter [M]. London: Flamingo, 2001.

[13] $\mathrm{Xu}$, Yingguo. British and American Literature in the perspective of Cultural Studies [M]. Beijing: People's Literature Publishing House, 2008.

[14] Zhang, Jiangjie. Chinese Traditional Family Intergenerational Ethics and Its Modern Transformation [D]. Shijiazhuang: Hebei Normal University, 2007 